\title{
Prezentacja książki Quod iustum est et aequum. Scritti in onore del Cardinale Zenone Grocholewski per il cinquantesimo di sacerdozio
}

Pięknie wydane dzieło Quod iustum est et aequum ${ }^{1}$ zawiera szereg tekstów różnorodnego rodzaju. Wszystkie one stanowią jedną całość, która zamierza wyrazić szacunek i wdzięczność ks. kardynałowi Zenonowi Grocholewskiemu z okazji jego złotego jubileuszu kapłaństwa. Złoty jubileusz - 50 lat kapłaństwa - to ukoronowanie długiego okresu życia. W przypadku kardynała Grocholewskiego to nie tylko długi okres, ale przede wszystkim czas wielkiej pracy dla dobra Kościoła i świata, co podkreślali autorzy przywołanych tekstów.

Pisze o tym w swoim liście gratulacyjnym papież Franciszek:

W uroczystość Najświętszej Trójcy w tym Roku Wiary przypada szczególny szczęśliwy jubileusz twego życia i posługiwania, mianowicie pięćdziesiąta rocznica twoich święceń kapłańskich. Bardzo chętnie zatem przez ten list gratuluję ci, Czcigodny Mój Bracie, który ze względu na ważny urząd i żarliwą gorliwość o dobro Kościoła powszechnego zaliczasz się do moich najbliższych współpracowników w winnicy Pańskiej.

Ojciec Święty po panoramicznym ukazaniu życiorysu Kardynała stwierdza:

Jestem pewien, że przez te minione pięćdziesiąt lat, prawie w całości poświęconych w służbie Kościołowi powszechnemu, na pewno bardzo często doświadczyłeś niewypowiedzianej dobroci miłosiernego i kochającego Boga [...]. Jednocześnie poprzez ten list gorąco gratuluję ci twojej długotrwałej i niestrudzonej pracy.

${ }^{1}$ Red. M. Jędraszewski, J. Słowiński, Archidiecezja Poznańska, Wydział Teologiczny Uniwersytetu Adama Mickiewicza, Towarzystwo im. Hipolita Cegielskiego, Poznań 2013. 
Swoje gratulacje przesłał także papież Benedykt XVI, który nawiązując do Roku Wiary, przekazuje Kardynałowi z okazji jubileuszu swoje błogosławieństwo. Papieże Franciszek i Benedykt XVI rozpoczynają długą listę osób przesyłających Kardynałowi gratulacje i życzenia. Na jej czele widnieją kardynałowie: Angelo Sodano, Stanisław Dziwisz i Stanisław Nagy, potem autorytety kościelne z Polski i z zagranicy, wyżsi przełożeni i przełożone zgromadzeń zakonnych męskich i żeńskich, autorytety naukowe z Polski i ze świata oraz władze państwowe i samorządowe z Polski.

Prezentowane dzieło bardzo konstruktywnie ukazuje pięćdziesięcioletni okres kapłaństwa, życia i działalności kardynała Grocholewskiego. Przedstawione są tam nie tylko fakty z życia i dokonania Kardynała, ale także środowiska, w których żył i pracował. Ukazane zostały jego strony rodzinne, miejsce urodzenia - Bródki koło Pniewa w Wielkopolsce, potem niższe seminarium w Wolsztynie, następnie wyższe arcybiskupie seminarium w Poznaniu, święcenia 27 maja 1963 roku w katedrze poznańskiej z rąk arcybiskupa Antoniego Baraniaka. Po święceniach, w latach 1963-1966, ks. Grocholewski pracował jako duszpasterz w parafii Chrystusa Odkupiciela w Poznaniu. W roku 1966 wyjeżdża do Rzymu, gdzie studiuje prawo kanoniczne na znanym w świecie Papieskim Uniwersytecie Gregoriańskim. Tam uzyskuje licencjat i doktorat z prawa kanonicznego. Promotorem zarówno licencjatu, jak i doktoratu jest wybitny, znany w świecie kanonistycznym profesor o. Ignatius Gordon SJ. Tytuł rozprawy doktorskiej brzmi: De Exclusione indissolubilitatis ex consensu matrimoniali eiusque probatione. Considerationes super recentiores sententias rotales. Promotor, profesor Gordon, prezentując doktoranta Zenona Grocholewskiego, napisał o nim: „Kapłan gorliwy i roztropny. Posiada charakter towarzyski i ujmujący, jest bardzo inteligentny". Zarówno za rozprawę licencjacką, jak i doktorską otrzymał Grocholewski Złoty Medal Uniwersytetu Gregoriańskiego.

Doceniając zdolności i przygotowanie ks. dra Grocholewskiego, profesorowie Uniwersytetu Gregoriańskiego zaprezentowali go jako kwalifikującego się do pracy w Kurii Rzymskiej. Za zgodą arcybiskupa poznańskiego podejmuje on w roku 1972 pracę w najwyższym trybunale Stolicy Apostolskiej, zwanym Sygnaturą Apostolską. Tutaj rozpoczyna się jego wieloletnia służba Kościołowi powszechnemu. W Sygnaturze Apostolskiej spełniał różnorodne funkcje, aż do prefekta tej dykasterii, którym został w 1998 roku, mianowany przez papieża Jana Pawła II. Wcześniej, w roku 1982, został przez niego mianowany biskupem, a 6 stycznia 1983 roku z jego rąk otrzymał święcenia biskupie. Warto dodać, że po święceniach biskupich Jan Paweł II zaprosił do siebie biskupa Grocholewskiego i ofiarował mu krzyż biskupi. Ten krzyż nosił poprzednio wybitny kanonista kard. Pietro Gasparri, który przygotował Kodeks prawa kanonicznego z 1917 roku, a następnie nosili go słynni kanoniści, kardynałowie Amleto Cicognani i Pericle Felici. Dziś można powiedzieć, że był to jakiś znak proroczy. W roku 1991 Jan Paweł II mianował biskupa Grocholewskiego arcybiskupem. W roku 1999 mianował go prefektem Kongregacji Wychowania Katolickiego, a w roku 2001 kreował go kardynałem, 
wyznaczając mu kościół tytularny San Nicola in Carcere. W wymienionych wyżej dykasteriach Kardynał sprawował funkcje przełożonego, poza tym należy jeszcze do innych licznych dykasterii i urzędów Kurii Rzymskiej.

Przywołaną bardzo ogólnie, ale niezwykle bogatą działalność kardynała Grocholewskiego opisali następujący autorzy: arcybiskup łódzki prof. dr hab. Marek Jędraszewski, biskup pomocniczy w Poznaniu dr Grzegorz Balcerek, biskup dr hab. Stanisław Napierała - biskup kaliski senior, o. prof. François-Xavier Durmotier SJ - rektor Uniwersytetu Gregoriańskiego, ks. dr Jan Słowiński - wykładowca na Uniwersytecie Poznańskim, ks. dr Rafał Rybacki - kurator Archiwum Archidiecezji Poznańskiej, prof. Giorgio Marino, ks. dr Paweł Malecha - promotor sprawiedliwości w Sygnaturze Apostolskiej, biskup prof. dr hab. Ignacy Dec - biskup świdnicki, biskup Zdzisław Fortuniak - biskup pomocniczy w Poznaniu, dr Marian Król - wojewoda poznański. Wymienieni autorzy ukazują kardynała Grocholewskiego jako wybitnego męża Kościoła, męża stanu, jako wybitnego uczonego kanonistę, niezwykle zasłużonego dla Kościoła, Kurii Rzymskiej i naszej ojczyzny, której dobre imię przez lata rozsławia po świecie. Za to został odznaczony przez prezydenta Rzeczypospolitej w roku 2009 Krzyżem Komandorskim z Gwiazdą Orderu Odrodzenia Polski.

Kardynał Grocholewski jest niezwykle wybitnym, znanym w świecie kanonistą. Przywołam następujące, znamienne wydarzenie. Wiosną 1982 roku Ojciec Święty Jan Paweł II przed promulgowaniem nowego Kodeksu prawa kanonicznego powołał szczególną komisję prawną w celu ostatecznego przygotowania tegoż Kodeksu. W jej skład weszło siedmiu najbardziej znanych kanonistów z całego Kościoła. Najmłodszym z nich był prof. Grocholewski. Parę miesięcy później, 25 stycznia 1983 roku, Jan Paweł II podpisywał nowy Kodeks. Na jednym ze zdjęć publikowanych w aneksie recenzowanej książki jest uwiecznione to wydarzenie. Wśród jego uczestników jest biskup Grocholewski, konsekrowany przez Jana Pawła II paręnaście dni wcześniej, 6 stycznia 1983 roku. Można sądzić, że podczas spotkań przywołanej wyżej komisji prawnej Grocholewski dał się poznać jako wybitny kanonista, co docenił Jan Paweł II.

Nie mogą więc dziwić liczne doktoraty honorowe, jakie w następnych latach otrzymał kardynał Grocholewski na różnych uczelniach w świecie. Jest ich dwadzieścia: Akademia Teologii Katolickiej w Warszawie (1998), Katolicki Uniwersytet Lubelski (1999), Uniwersytet w Passau (2001), Uniwersytet w Glasgow (2001), Uniwersytet Komeńskiego w Bratysławie (2002), Papieski Uniwersytet Katolicki w Buenos Aires (2002), Uniwersytet Fu Jen w Taipei na Taiwanie (2003), Uniwersytet Adama Mickiewicza w Poznaniu (2004), Uniwersytet w Bukareszcie (2006), Uniwersytet w Osijeku na Chorwacji (2007), Fordham Uniwersytet w Nowym Jorku (2008), Uniwersytet w Cluj-Napoka w Rumunii (2009), Uniwersytet Katolicki Goias w Brazylii (2009), Uniwersytet Katolicki w Walencji (2009), Uniwersytet Katolicki w Nairobi, Kenia (2010), Uniwersytet Katolicki w Budapeszcie (2010), Uniwersytet Al. J. Cuza w Rumunii (2010), Uniwersytet w Katowicach (2010), Uniwersytet Katolicki w San 
Cristobal w Wenezueli (2012), Uniwersytet w Salta, Argentyna (2013), Uniwersytet Katolicki w Rużomberoku, Słowacja (2013).

W księdze pamiątkowej swoje artykuły umieścili następujący kanoniści: Manuel Jesús Arroba Conde, Philip J. Brown, Raumond Leo Burke, Ariel David Busso, Frans Daneels, Ginter Dzierżoń, Péter Erdö, Wojciech Góralski, Józef Krukowski, Joaquin Llobell, Klaus Lüdicke, Gianpaolo Montini, Bartosz Nowakowski, Nikolaus Schöch, Hugo Schwendenwein, Henryk Stawniak, Lucjan Świto.

Kardynał Grocholewski od 1999 roku jest prefektem Kongregacji Edukacji Katolickiej. Zajmuje się ona kierowaniem, w imieniu papieża, całokształtem oświaty i wychowania w Kościele katolickim. Podlegają jej szkoły katolickie na wszystkich szczeblach, począwszy od przedszkoli i szkół podstawowych, poprzez szkoły ponadpodstawowe, średnie, po uczelnie wyższe i uniwersytety. W księdze pamiątkowej są umieszczone artykuły związane z działalnością Kongregacji Edukacji Katolickiej. Napisali je następujący autorzy: Britt-Mari Barth, Friedrich Bechina, Sjur Bergan, Walter Brandmüller, Doyen Philippe Capelle-Dumont, Herminio V. Dagohoy, Giuseppe Dalla Torre Del Tempio di Sanguinetto, Adalbert Denaux, Jean-Paul Durand, Jaime Emilio González Magana, James J. Hennessy, Andrei Marga, Janusz Mastalski, Wiesław Mering, Jerzy Myszor, Hein M. C. M. van Oorschot, Luciano Pazzaglia, Jan Sadlak, Marcelo Sánchez Sorondo, Elio Sgreccia, Manlio Sodi, Jan Szpet, Gu-y-Réal Thivierge, Jerzy Troska, Robert Tyrała, Etienne Verhack, Alfredo Horacio Zecca.

Kardynał Grocholewski jest wielkim kanclerzem: Papieskiego Uniwersytetu Gregoriańskiego, Papieskiego Instytutu Muzyki Sakralnej, Papieskiego Instytutu Archeologii Chrześcijańskiej i Papieskiego Instytutu Studiów Arabskich i Islamskich.

Prezentowane dzieło: Quod iustum et aequum stanowi wyraz hołdu i czci dla kardynała Zenona Grocholewskiego z okazji jego złotego jubileuszu kapłaństwa. Zawiera także życzenia dla dostojnego jubilata. Ich zwornikiem są słowa papieża Franciszka:

Te życzenia potwierdzam moim apostolskim błogosławieństwem, którego - jako zadatku niebieskiej łaski - udzielam z wielką miłością najpierw tobie, Czcigodny Mój Bracie, świętującemu szczęśliwy Złoty Jubileusz święceń kapłańskich, a także chcę, by szczodrze mieli w nim udział pozostali kapłani owego dnia wyświęceni razem z tobą, twoi krewni i współpracownicy, i wszyscy uczestnicy twojej wielkiej radości. 
